\title{
Eş anlamlı kelime öğretimi açısından Fakir Baykurt'un Eşekli Kütüphaneci romanı
}

\section{İsmail ÇOBAN ${ }^{1}$}

\section{Faruk POLATCAN2}

\begin{abstract}
APA: Çoban, İ; Polatcan, F. (2020). Eş anlamlı kelime öğretimi açısından Fakir Baykurt'un Eşekli Kütüphaneci romanı. RumeliDE Dil ve Edebiyat Araştırmaları Dergisi, (Ö7), 224-236. DOI: 10.29000/rumelide.808484.
\end{abstract}

\section{$\ddot{O ̈}_{z}$}

Eş anlamlılık, iki ya da daha çok sayıda göstergenin aynı anlama gelme, ayrı gösterenlerin aynı gösterileni belirtme özelliğidir. Herhangi bir konu ile ilgili eş anlamlı kelimelerin sayıca fazla olması o dilin gelişmişlik düzeyinin göstergelerinden biridir. Ana dili ve yabancı dil öğretiminde kelime öğretimi önemli bir yer tutmaktadır. Eş anlamlı kelimelerin öğretimi, kelime öğretiminin önemli bir bölümünü oluşturmaktadır. Bu nedenle dil öğretimi kitaplarında eş anlamlı kelimelerin öğretimine yönelik pek çok etkinlik örnekleri bulunmaktadır. Tarama modelinde yapılan bu araştırmada Fakir Baykurt'un Eşekli Kütüphaneci adlı romanı eş anlamlı kelimelerin öğretimi açısından değerlendirilmiştir. Doküman incelemesi yöntemiyle toplanan verilerin analizinde, nitel veri analizi yöntemlerinden betimsel analizden yararlanılmıştır. Eşekli Kütüphaneci’de kullanılan eş anlamlı kelimelerden "konuk”, “aygıt”, “işgören”, “ayırt”, “ayaktopu”, “sevi” ve “doyumevi”nin geçiş sıklıklarının 4 ve daha fazla kez olduğu tespit edilmiştir. Diğer kelimelerin geçiş sıklıklarının ise 1 ila $3 \mathrm{kez}$ arasında olduğu görülmektedir. 30 farklı kelimenin yerine toplam 80 kez eş anlamlıları kullanılmıştır.

Anahtar kelimeler: Eş anlamlı kelime, kelime öğretimi, dil bilgisi öğretimi, Eşekli Kütüphaneci.

\section{A review of the novel Eşekli Kütüphaneci by Fakir Baykurt with respect to the teaching of synonymous words}

\begin{abstract}
Synonymy describes in which two or more signs have the same meaning, in other words, different signifiers represent the same signified. The large number of synonymous words related to a certain subject is an indicator of the development level of a language. Vocabulary education holds an important place in teaching the mother tongue and any foreign language. The teaching of synonymous words is a major part of vocabulary education. Therefore, language course books contain many examples of activities aimed at the teaching of synonymous words. In this research, which is based on survey model, the novel Eşekli Kütüphaneci by Fakir Baykurt has been reviewed with respect to the teaching of synonymous words. Collected by using document review method, the data were analyzed using descriptive analysis as a method of quantitative data analysis. It was determined that among the synonymous words used in Eşekli Kütüphaneci,"konuk”, "aygıt”, "işgören”, "ayırt”, "ayaktopu”, "sevi” and "doyumevi” had an occurrence frequency of 4 or more.
\end{abstract}

1 Dr. Arş. Gör., Artvin Çoruh Üniversitesi, Eğitim Fakültesi, Türkçe ve Sosyal Bilimler Bölümü, Türkçe Eğitimi ABD (Artvin, Türkiye), smlcoban@gmail.com, ORCID ID: 0000-0003-3952-9350 [Makale kayıt tarihi: 24.08.2020-kabul tarihi: 20.10.2020; DOI: 10.29000/rumelide.808484]

2 Doç. Dr., Sinop Üniversitesi, Eğitim Fakültesi, Türkçe ve Sosyal Bilimler Bölümü, Türkçe Eğitimi ABD (Sinop, Türkiye), farukpolatcan@gmail.com, ORCID ID: 0000-0002-6897-8932 
Occurrence frequency of the other words were found to be varying between 1 - 3 times. 30 different words were replaced with their synonyms for 80 times in total.

Keywords: Synonymous word, vocabulary teaching, grammar education, Eşekli Kütüphaneci.

\section{Giriş}

Dile eserlerinde yaşama imkânı sunanlar dilin gelecek kuşaklara da aktarılmasında önemli pay sahibidirler. Türk edebiyatında bunu sağlayan, dili yerel konuşma ağızları, standart biçimi ve yabancı etkilerden arınmış hâliyle sunan isimlerden birisi de Fakir Baykurt'tur.

Eserlerinde Türkçenin zengin ve gelişmiş dil kullanımlarını görmek mümkündür. Halk dilinde yaşayan ancak yazı dilinin çeviriminde yer almamış söz varlığının (deyim, atasözü, kalıp söz, ikileme, yerel sözcükler $v b$.), yazı diline girmesinde önemli rol oynamıştır (Yazıcı Okuyan, 2007). Fakir Baykurt'un Türkçenin kalıplaşmış dil ögelerine eserlerinde sıklıkla yer verdiği görülmektedir. "Yllanların Öcü romanında 2,65 sayfada 1 olmak üzere 103 deyim, 8,80 sayfada 1 olmak üzere 31 atasözü, 1 sayfaya 2,31 olmak üzere 632 ikileme ve 1 sayfaya 1,39 olmak üzere 380 yinelemeden oluşmuş ikileme kullanmıştır" (Akyalçın ve Gürcü, 2017, s. 65). "Amaç, anlam, başkan, bilim, dilekçe, gömüt, gömütlük, görev, ilgi, irdelemek, işlem, kesin kesinleşmek, komut vermek, neden, olanaksız, onaylamak, önem, öneri, önermek, özel, varsıl, yaşam, yarar, yararlı yetki, yoksun, yöntem, zorunlu” (Yanardağ, 2005, s. 469) bu kullanımlardan sadece birkaçıdır.

Fakir Baykurt, kelime seçiminde olduğu gibi anlatımda da halkın değerlerine bağlanır. Dil dünyasına girdiği kişilerin söyleyişlerini de en ince ayrıntılarına kadar gözlemler. Onların umutlarını, umutsuzluklarını, acılarını, sevinçlerini, kısaca hayat maceralarını Türkçenin güzel ifadeleriyle sergiler (Yanardağ, 2005, s. 465).

Fakir Baykurt eserlerinde "köy gerçekliğini, köylünün yoksulluğunu, parasızlığı, hayatını idame etmek için çektiği sıkıntılar, sağlık, ulaşım, beslenme, imam ile öğretmen ve ağa ile ırgat çatışması, köylülerin devletle olan ilişkileri, cezaevleri, öğretmenlik anıları ve eğitim sorunu” (Suvağci, 2019, s. 109) konularından beslenmiştir.

Baykurt, önceleri şiirle devam ettiği edebiyat yolunda daha sonra hikâye ve romana yönelir. "Fakir Baykurt, nesir alanına hikâyeci olarak girer. Hikâyeciliği bir süre denedikten sonra romancıllğa geçer" (Yanardağ, 2007, s. 227). Fakir Baykurt'un roman, öykü, toplum ve eğitim yazıları, çocuk kitapları ve şiir başlıkları altında sınıflandırılabilecek birçok eseri bulunmaktadır (Efe ve Asutay, 2018, s. 4-5).

Baykurt'un eserlerinden birisi de Eşekli Kütüphaneci'dir. Eşekli Kütüphanecinnin yazımı hakkında Baykurt şunları dile getirmektedir: "Yarın bir yolculuğa çıkacağım. Ve Orta Anadolu'da bir zamanlar eşeksırtında köylere kitap taşıyan ve Eşekli Kütüphaneci diye ün yapmış olan Mustafa Güzelgöz’ü arayıp bulacağım ve onunla konuşacağım. Elimden gelirse onun biyografisini yazacağım” (Hızlan, 2001).

Eşekli Kütüphaneci Türk kütüphaneciliğinde yaptıklarıyla ün kazanmış olan Mustafa Güzelgöz’ün hayatını ele almaktadır. Mustafa Güzelgöz, gezici kütüphane faaliyetlerinde akla gelen ilk isimlerdendir. "Güzelgöz bu hizmeti 1957 yllında Ürgüp’e bağlı üç köyde eşeklerden yararlanarak başlatmıştır. 1959 yllında Ürgüp Tahsinağa Kütüphanesi beş merkep (eşek), üç at ve bir katır ile gezici kütüphane hizmeti veren bir kurum hâline gelmiştir" (Öksüzoğlu, 2016, s. 263). 
A review of the novel Eşekli Kütüphaneci by Fakir Baykurt with respect to the teaching of synonymous words / İ. Çoban; F. Polatcan (pp. 224-236)

Eserde yazarın üslubu özellikle de kelime tercihleri dikkat çekmektedir. Eserin öğrencilerin kelime dağarcığını geliştirme -özellikle eş anlamlı kelime- açısından yararlanılabilecek bir kaynak olduğu görülmektedir. Dilin kendi iç zenginliği ve alıntı yoluyla bünyesine kattığı kelimeler sayesinde dilde eş anlamlı kelimeler dikkat çekmektedir. Eş anlamlı kelimeler anlatıma farklılık ve güç kattıkları gibi öğretimleri de Türkçe öğretimi süreçlerinde yer almaktadır. Türkçe Dersi Öğretim Programı’nda 5 . sınıf okuma kazanımları içerisinde "Kelimelerin eş anlamlılarını bulur." ifadesi yer almaktadır (MEB, 2019).

Eş anlamlı kelimeler, anlamları aynı olan veya birbirine yakın olan kelimelerdir. Dil bilimi açısından aslında anlamca birbirine tıpı tıpına denk düşen çok az kelime vardır. Eş anlamlı sözler, genellikle bazı kelimelerdeki kavram inceliklerinin çeşitli sosyal ve dil kesimlerinde zamanla gölgelenmeye uğrayarak anlamca birbirlerine yaklaşmalarından oluşmuştur (Korkmaz, 2017, s. 128). Eş anlamlılık, sözcük ve tümcelerin özdeş anlamlı olmaları durumudur. Anlam bilimciler tam eş anlamlılığın söz konusu olmadığını, çünkü böyle bir durumun ancak iki sözcük bütün bağlamlarda birbirinin yerine kullanılabilirse olanaklı olabileceğini öne sürerler (İmer, Kocaman ve Özsoy, 2011, s. 118)

Eş anlamlılık, iki ya da daha çok sayıda göstergenin aynı anlama gelme, ayrı gösterenlerin aynı gösterileni belirtme özelliğidir. Örneğin siyah ve kara birçok bağlamda eş anlamlılık gösteren ögelerdir. Eş anlamlılık çoğu kez salt nitelikli olmaktan uzaktır, bu nedenle özdeşlikten çok, anlamca yakınlık belirtir. Çünkü aynı bağlamda hiçbir anlam ayırtısı getirmeden birbirinin yerini alabilecek göstergeler az sayıdadır (Vardar, 2002, s. 94; Altınörs, 2000, s. 30).

Eş anlamlı kelimeler genel olarak birbirlerinin yerlerine kullanılabilirler. Fakat bazı kelimelerde anlam farklılıkları olabilmektedir. Bu nedenle sözlükler hazırlanırken eş anlamlılık analizlerinin titizlikle yapılması gerekmektedir (Doğan, 2011, s. 87). Eş anlamlılık bağlam çerçevesinde düşünülmelidir. Eş anlamlılık tam bir anlam özdeşliğini değil, güçlü bir anlam benzerliğini ifade eder (Sert, 2019, s. 115).

Eş anlamlı kelimelerin tamamen birbirini karşılamadığına yönelik görüşler mevcutken, bazı görüşler de bunun aksini savunmaktadır. "Bloomfield'a göre gerçekte eş anlamlı kelimeler yoktur. Dil alanında yapılan çağdaş araştırmaların ışığında bu görüş çürütülmüştür ve dilde eş anlamlılığın varlığı kanıtlanmıştır. Özellikle yabancı sözcük alışverişi, bir dilde eş anlamlılı̆̆ geliştirici olmuştur" (Demirezen, 1991, s. 133). "Bir anlamı karşılamak için başka bir dilde üretilmiş bir kelime birçok kez doğrudan alınarak kullanılmaktadır. Dillerin söz varlığındaki yabancı kelimeler bu durumun sonucudur" (Karadă̆, 2013, s. 34). Dilin bünyesindeki yerli kökenli eş anlamlıların bolluğu dilin anlatım gücünü arttırmaktadır (Özden, 2014, s. 162).

Türk dilinde özellikle kullanırın toplumdaki statüsüne, cinsiyetine, yaşına, bağlı olduğu toplumun kültürel özelliklerine, düşünce yapısına, zamana, teknolojinin gelişimine bağlı olarak kavramlara yüklenen karşılıkların değişim göstermesiyle oluşan anlam farklılıkları ve sözcüklerin kullanıldıkları alan, tarz ve üslup özelliklerine göre gösterdikleri farklılıklardan oluşan bilişsel eş anlamlıların fazlalığı göze çarpmaktadır (Pilten, 2008, s. 483).

Tarih boyunca sözcükbilim açısından yapılacak bir inceleme Türkçenin sözvarlığının eş anlamlılar bakımından zenginliğini gösterecektir. Eski Türkçe Dönemi metinlerinde tam eş anlamlılık sayılabilecek olan tün ve kiçe (gece), küç (güç) ve erk sözcüklerinin yanı sıra pek çok Türkçe kökenli eş anlamlılara rastlanır. Örneğin yinçge (ince) ve yuyka (bugünkü yufka), ögmek ve alkamak 'övmek', kut 
ve ülüg 'şans, baht, talih', 'kötü' kavramını yansıtan yabız (yavuz), yablak, anıg sözcükleri, 'tatlı' anlamındaki tatıglıg ve süçig bunlardan ancak birkaçıdır (Aksan, 2006, s. 126; Alyılmaz, 2004).

Türkiye Türkçesindeki eş anlaml kelimelerin genel özelliklerini şu şekilde dikkatlere sunmak mümkündür:

1. Bütün dillerde olduğu gibi Türkçede de yüzde yüz eş anlamlllı mümkün değildir.

2. Türkçenin tarihî dönemlerinde eș anlamlı biçimde kullanılan kelime çiftlerinden bazıları Türkiye Türkçesinin söz varlı̆̆ında kullanılmamaktadır. Eş anlamlılık sözcük ölümüne neden olmaktadır.

3. Eş anlamlı görünen kelimeler arasında zaman içinde anlam nüansı oluşabilir. Lokanta, restoran; ulusalcı, milliyetçi; ulusalcılık, milliyetçilik sözcükleri arasında anlam farkı bulunmaktadır.

4. Aynı anlama gelen yerli ve ödünç kelimeler arasındaki ilişki anlamdaşlık biçiminde açıklanmamalıdır.

5. Eş anlamlılık bakımından standart Türkçe ile Türkiye Türkçesi ağıları arasında fark bulunmaktadır (Sar1, 2011, s. 538).

Cumhuriyet'e, Dil Devrimi'ne kadar süregelen yabancı sözcük akımı, yerlileriyle bir arada yaşayan birçok yabancı ögenin dilde tutunmasına neden olmuştur. Tanzimat’tan sonra Fransızcanın, II. Dünya Savaşı'ndan başlayarak İngilizcenin güçlü etkisi Türkçedeki eş anlamlıların bir başka yoldan artmasına yol açmıştır. Bu durumun izleri bugünkü Türkiye Türkçesinde de görülmektedir (Aksan, 2006, s. 126127).

Bugün Türkiye Türkçesindeki eş anlamlıları, her ögesi Türkçe olanlar ve Türkçesiyle birlikte yabancı ögeleri de yaşayanlar şeklinde sinıflandırmak mümkündür (Aksan, 2006, s. 127). Eş anlamlı kelimelerin öğretiminde de dikkat edilmesi gereken bazı durumlar vardır. Ders kitaplarında yer alan etkinliklerin ve öğretmenin kendisinin oluşturacağı etkinliklerin tekdüzelikten uzak olması gerekmektedir. "Eş anlamlı kelimeleri bir arada verme etkinliği yapılırken sınıf düzeyi dikkate alınmalıdır" (Özbay ve Melanlığlu, 2008, s. 37). Bir kelime öğretilirken, varsa zıt ve eş anlamıyla birlikte öğretilmelidir. Zira bu şekilde kelimelerin anlamı daha kolay kavranır ve daha rahat hatırlanır. Tekrardan kaçınmak için, eş anlamlı ve zıt anlamlı kelimelerle sözcük öğretimi gerçekleştirilmelidir (Büker ve Zeytinkaya, 2013, s. 189).

Eş anlamlı kelimelerin Türkçe ders kitaplarındaki yeri hakkında yapılan çalışmalar eş anlamlı kelimelerin Türkçe eğitiminde öğretilmesine, kavratılmasına önem verilen bir konu başlığı olduğunu göstermektedir. Gündoğdu'ya (2012) göre eş anlamlı kelimelerin öğretimine yönelik olarak 6. Sınıf Türkçe Dersi Öğrenci Çalışma Kitabı'nda 7 etkinliğin bulunduğu ve bunların sözcük öğretimi ile ilgili etkinliklerin \%14’ünü kapsadığı tespit edilmiştir (Gündoğdu, 2012). Türkçe dersinde sözcük öğretme yöntemleri içerisinde eș anlamlarını bulma etkinliklerin 65 sözcük ve \%17,1'lik bir oranla yer aldığı bilgisine yer verilmektedir (Dilidüzgün, 2014). Ortaokul 5. Sınıf Türkçe Ders Kitabı’nda (2018) ve Türkçe Dersi Öğrenci Çalışma Kitabı’nda (2017) bulunan sözcük öğretimi etkinliklerinde eş anlamlı kelime bulma etkinliklerine ders kitabında 4 (\%4,30); çalışma kitabında $3(\% 3,94)$ kez yer verildiği belirtilmiştir (Bayraktar, 2018, s. 5).

Başar, Batur ve Karasu'ya (2014) göre uygulama ve kalıcılık çalışmalarında eş anlamlı kelimeleri tanıma oranı zıt anlamlıları tanıma oranının yarısından daha az bulunmuş; bu durum öğrencilerin eş anlamlı kelimeleri yeterince tanımadıkları ve eş anlamlı kelimelerin kavratılmasında da sınıf içi etkinliklerle sözcük öğretimine yönelik çalışmanın yapılmadığı ile açılanmıştır (Başar, Batur ve Karasu, 2014, s. 918). 
A review of the novel Eşekli Kütüphaneci by Fakir Baykurt with respect to the teaching of synonymous words / İ. Çoban; F. Polatcan (pp. 224-236)

Kelime hazinesi çalışmalarının bir amacı pasif kelime hazinesini zenginleştirmekse diğeri de aktif kelime hazinesini zenginleştirmektir. Pasif kelime hazinesini geliştirmek için;

a. Öğrencinin yazılı ve sözlü metinlerle karşılaşmasını sağlamak,

b. Kelime oyunları, bulmacalar, bilmeceler $v b$. içeren etkinliklerden yararlanmak,

c. Sözlük kullanmak gibi çalışmalar yapılmalıdır (Çeçen, 2007, s. 133).

Türkçe dersi kitaplarında geçen kelimelerin öğretimi, öğrencilerin zengin kelime servetine sahip olmasına yeteri kadar katkı sağlamadığı ortadadır. Öğretmen, ders kitabı dışında diğer basılı materyallerden gazete, dergi, broşür, hikâye, roman, çizgi roman $v b$. kullanımı, bu materyallerde geçen kelimelerin öğretimi ile öğrencilerin kelime hazinesini geliştirme yoluna gitmeli, metin içinde geçen kelimelerin anlamlarını öğrencilerin sezmesini sağlamak için konuyla ilgili resimlerden faydalanmalıdır (Karatay, 2007, s. 149).

Eş anlamlı kelimelerin de öğretiminin sınıf ortamında sınırlı kalmaması gerekmektedir. Öğrencinin öğrendiği bilgilerle okul dışında da karşılaşması, bunlarla gerçek hayatta da karşılaşması gerekmektedir. Öğrencilerin okudukları kitaplar bu durumu desteklemelidir. Bu doğrultuda "Eşekli Kütüphaneci romanının eş anlamlı kelimelerin öğretilmesi ve kalıcılığını sağlamadaki rolü nedir?” sorusuna bu çalışmada cevap aranmıştır.

\section{Yöntem}

\section{Araștırmanın modeli}

Fakir Baykurt'un Eşekli Kütüphaneci adlı romanını eş anlamlı kelimelerin öğretimi açısından değerlendirmek amacıyla tarama modelinde yapılan bu çalışmada nitel araştırma tekniklerinden yararlanılmıştır. Tarama modelinde, belirli özellikleri tespit edebilmek için verilerin toplanması amaçlanmaktadır. Modelin en önemli avantajı birçok bilginin bir arada verilebilmesidir (Büyüköztürk vd., 2016).

\section{Verilerin toplanması ve analizi}

Araştırma verileri nitel araştırma yöntemlerinden doküman incelemesi yöntemiyle elde edilmiştir. Doküman incelemesi ile belli bir döneme tanıklık etmiş; fakat artık yaşamayan kimselerin anı, otobiyografi, günlükler, köşe yazıları $v b$. metinleri hakkında ayrıntılı bilgiler, beceriler elde edilebilir. Böyle durumlarda gözlem ve görüşme yapılamadığından doküman analizi büyük kolaylık sağlar (Ulutaş, 2015, s. 284).

Doküman incelemesi yöntemiyle toplanan veriler nitel veri analizi yöntemlerinden betimsel analiz kullanılarak değerlendirilmiştir. Betimsel analizde elde edilen veriler öncelikle sistematik bir şekilde, açıkça betimlenir. Daha sonra bu betimlemeler; açıklanıp yorumlanır, neden-sonuç ilişkileri belirlenir ve bazı sonuçlara ulaşılır (Yıldırım ve Şimşek, 2013, s. 256).

Araştırma verilerinin güvenirliğini sağlayabilmek için veriler 2 kodlayıcı tarafından tespit edilmiştir. Elde edilen verilerden yaşanan uyumsuzluklar kodlayıcıların ortak incelemesiyle karara bağlanmıştır. 
Nitel araştırmalarda geçerlik ve güvenirlik iki ya da üç araştırmacının veri analizine katılmasıyla sağlanabilir (Dinç, 2013, s. 206).

Yapılan inceleme sonucunda belirlenen eş anlamlı kelimeler, parantez içerisinde eş anlamlılarıyla gösterilmiş; ardından da kelimenin eserde geçtiği bölüme yer verilmiştir.

\section{Bulgular}

Eşekli Kütüphaneci adlı romanda kullanıldığı tespit edilen eş anlamlı kelimeleri şu şekilde dikkatlere sunmak mümkündür:

\section{yazıcı (resepsiyon)}

Dimitrios Katsikas, şehrin ortasında bir otelin kapısından girdi. Burası eski yapı küçük bir otel. Tahta yapısı yakınlarda bir onarm geçirmise benziyor. Orasina burasina beton dökmüssler. Yazıcı delikanl, kaydını yaptıktan sonra onu ikinci kata çıkardı. Kalacağı odayı gösterdi. s. 8.

Dimitrios iki günlük yatak parasını ödemek için yazncmnn önüne gittiğinde borcunun ödenmiş olduğunu öğrendi. s. 24

\section{gömüt (mezar)}

Benim öyküyü soruyorsun. Karnıma katıp gömüte mi götüreceğim; onu da anlattrm, ne olacak? s. 21

Öğretmenin biri de benim hesap saz çalıyormuş. Eee, saz da günah. Saz çalan adamın babasının gömütüne sirtlan girer. s. 44.

Yerin üstünde yer mi tükendi? Bizi niçin diri diri gömüte sokuyorsun canım, Mustafa Bey? s. 71

\section{doyumevi (lokanta)}

Dimitrios akşam yemeğini Aziz’le birlikte kaya içine oyulmuş bir doyumevinde yedi. s. 22

Sazın yanında keman ile dümbelek çalıyorlar. Hem de doyumevinde çalınan saz Refik Başaran'in sazı gibi çalı sürüntüsüne benzemiyor. s. 22

Doyumevinden çıktıklarında gece epey ilerlemişti. s. 23

Mustafa Bey'in sık sık oraya gidip gelmesi gerekiyor. Gitti mi, otelde yatıyor. Doyumevinde yiyor. Bu işlerin hangisi parasız döner? s. 74

Bir gün gene peri kayalıklarına oyulmuş doyumevine gidip eğlendiler. s. 117

\section{anapara (sermaye)}

Burda kalıp bir dükkân açayım desem, beş on kuruş anapara gerekir. Ben nerden bulayım anaparay?? s. 24

\section{yapı (bina)}

Sonra çantasından küçük bir albüm çıkardı. Nineleri kimdir, hangisi hangisidir, Anastasia Teyze kimdir; Larisa'nın genel görünüşü, belediye yapısı, Belediye Caddesi, Selanik'te Üniversite Caddesi, üniversite yapıları, antlar, büyük ağaçlar; cadde üstï kahvelerde oturan erkekler; evlerin penceresini, balkonu çiçeğe boğmuş, hem de her yeri ak kireçle badana etmiş kadınlar; akşamüstü, tam piyasa vakti kız erkek birbiriyle kol kola yürüyen delikanlların fotoğraflarmı tek tek gösterdi. s. 26

Aziz Güzelgöz, Ürgüp Belediye yapısının merdivenlerinden kuş gibi uçarak indi. s. 121 
A review of the novel Eşekli Kütüphaneci by Fakir Baykurt with respect to the teaching of synonymous words / İ. Çoban; F. Polatcan (pp. 224-236)

\section{yapit (bina)}

Kimi yerlerde köylüler adamı yapıtları bulunduğu yerlere sokmak istemiyor; ama o yetkililerden aldığı özel izinle girip işini görüyor. s. 82

\section{mallı (servet)}

Onlar bizi küçümser. Kendilerini mall sanıyorlar. Başka kız beğen! s. 28

Kızların bir memura vereceklermiş; ama küçük bir memura değil, müdüre, müfettişe! Çünkü hem mall, hem çok güzelmiş. s. 28

\section{sevi (sevda)}

"Sen beni kaçıramazsın; çek atını, ben seni kaçıracağım!" dedi. O an anladım ben durumu. Anladım sanıyorum. Şu dünyadan ne sevi'ler gelip geçmiş değil mi? Böylesini de ilk görüyorum. S. 29

Kitap sevisi yüzünden benim Eşekli Kitaplık işine koyulmamın bir nedeni daha var; bu neden beni çok tedirgin ediyordu. s. 46

Onda doğuştan maç sevisi var. Herkeste kitap sevisi olacak değil ya. Olsa ne iyi olur oysa. s. 50

Bu iş sevi'yle, yani aşkla yapılır ya da yapılmaz! s. 105

\section{yaşam (hayat)}

Ama gönlü olursa, İstanbul'a da ikimiz birlikte gideriz. Veririz surt surta. O da çok iyi bir yaşam olur. s. 30

\section{yanit (cevap)}

Mustafa sordu Hanife'ye: “Söyle canım, yanıtını bilmek istiyorum. Ne diyorsun?” s. 32

\section{ayaktopu (futbol)}

Bir yandan da Kaymakam Bey sıkıştırıyor: "Ne oldu, ayaktopu takımın kurdun mu evladım?” s. 35

Ben de ona, bundan böyle Ürgüp ayaktopu takımını çok iyi çalş̧tıracağım diye söz verdim. s. 49 İncesu'yla yaptığımız ayaktopu maçında altı gol attık. s. 50.

Biz de gençler için ayaktopu takımı isteriz. Biz de kooperatif isteriz. s. 60

Törenden sonra Mustafapaşa ile Taşkınpaşa ayaktopu takımlarının maçı vardı. s. 63

Yakında burda, tıpkı Ürgüp’teki gibi bir ayaktopu takımı kuracağız. s. 73

Mustafa Bey 1944'te bu işe atanınca, Kaymakam’n isteği üzerine kasabanın gençlerini toplayıp biraz ayaktopu çalıştırmakla yetinebilirdi. s. 87

İşe ayaktopu takımına aldığı gençleri okutmakla başladı. s. 87

\section{varsıl (zengin)}

Varsıl biri olmadiğım hâlde çok mal kestim. Bol bol etleri pişirtip tabaklara doldurduk, yedirip içirdik. s. 38

Ístanbul'da, Ankara'da ne kadar Ürgüplü hemşerimiz varsa, bu önemli, bu önemsiz, bu varsıl, bu yoksul ayırmadan hepsinin adresini topladrm. s. 53

Doğrusu kız da beni seviyordu. Ama ana babası biraz varsıldır. Biz de yoksuluz onlara göre. s. 57 


\section{ayırt (fark)}

Mustafa Bey, insanların içinde o güne kadar pek ayırdında olmadığı derin bir iyilik özlemi olduğunu sezdi. s. 64

Şimdi üstünden yıllar geçince düşünüyorum da, büyük bir, hatta iki hata yaptığımın ayırdına vartyorum. s. 92

Ayırdına vardın değil mi; çok önemsediğim için Halkevlerini, Köy Enstitülerini, dönüp dönüp söylüyorum. s. 112

Hanife Hanım ona yant verdi: "Gâvurla Müslüman’n arasındaki ayırt, soğanın zarı kadar...” s. 125

Kapadokya yöresinden kalkıp giden yurttaşların kendilerinden hiçbir ayırdı yoktu. s. 135

\section{yarayışılı (faydalı)}

Hemşerilerimiz olarak bizi gazetelere, yarayışh dergilere abone yazdırırsanız, ayrıca seviniriz. S. 54

\section{ün (nam, söhret)}

Gün geçtikçe ünümüz büyüyor. Artık kütüphanemize çeşitli dergiler, gazeteler geliyor. s. 56

Eşekli Kütüphanecïnin ünü böyle alp yürüyünce, Amerikan Elçisi Parker T. Hart da yardımclarıla birlikte ziyaretine geldi. s. 84

\section{taşıt (vasıta)}

Taşıt denk geliyor mu? Geliyor elbet; kimi zaman kamyon, kimi zaman cip, minibüs, şu bu. s. 61

Toplantılara yetişmek için taşıt tutuyorum. s. 91

\section{işgören (hizmetli, müstahdem)}

Zile basıp işgöreni çă̆ırdı, çıkardı Mustafa Bey’i dışarı. s. 72

İsgörren onu yeniden Genel Müdür'ün huzuruna götürdü. s. 72

Devlet Planlama'da Ürgüplü biri vardı. Salim Mermer, küçük bir işgörendi. s. 78

Görevlilerden birine nerden geldiğini sordum. Ben Gebze'de işgörendim. s. 105

\section{aygit (cihaz)}

O zaman şimdiki gibi fotokopi aygıt yok. s. 53

Üzümler eskisi gibi ayakla değil, pres denilen aygttarla sıkılıyor. s. 72

Ill merkezinden gelen teknik elemanlar sesbüyüten, sesdağıtan aygıtların birbirine bağlayıp, sağda solda dikili direklere astyorlardı. s. 101

Hanife’ye hemen aygtt bağladılar. Ölçüm biçim yaptılar. s. 109

\section{sesbüyüten / sesdağıtan (hoparlör)}

İl merkezinden gelen teknik elemanlar sesbüyüten, sesdağıtan aygıtlarını birbirine bağlayıp, sağda solda dikili direklere asıyorlardı. s. 101

\section{buyruk (emir)}

Eşekle köylere kimseden buyruk almadığı hâlde kitap dağıttı. s. 78 
A review of the novel Eşekli Kütüphaneci by Fakir Baykurt with respect to the teaching of synonymous words / İ. Çoban; F. Polatcan (pp. 224-236)

\section{konuksever (misafirperver)}

Şu anda Ürgüp’ün dünyada ender güzellikleri içinde, konuksever ve çok yaratıcı insanlar olan Ürgüplüler arasında bulunmaktan eşim ve ben derin bir hoşnutluk duymaktayız. s. 85

\section{hoșnutluk (memnuniyet)}

Şu anda Ürgüp’ün dünyada ender güzellikleri içinde, konuksever ve çok yaratıcı insanlar olan Ürgüplüler arasında bulunmaktan eşim ve ben derin bir hoşnutluk duymaktayız. s. 85

\section{yalınlık (sadelik)}

Besbelli değil mi, Mustafa Güzelgöz'ün başarısında insanı şaşırtan başlıca özellik, onun yalınlığıdir. s. 87

\section{önder (lider)}

Köylülere her alanda rehber olmaya başladı. Bölge kalkınma önderi seçildi. s. 88

Mustafa Bey, “Bölge Kalkınma Önderi” seçilince büyük umutlara kapıldı. s. 89

Ben bu işleri yaparken, valiler toplanıp beni bölge kalkınma önderi ilan etti. s. 91

\section{ivedi (acele)}

Neden o kadar ivedi davrandın? Gerçi çalsşacaksın da, değer mi bilecekler? s. 99

"Programda bulunmasını arzu ettiğiniz hususlar ve ayrıca çağrılmasın istediğiniz konuklar varsa, bunlar bize ivedilikle bildirmenizi rica ederim" diye yazıyor. s. 100

\section{değerbilir (kadirşinas)}

Hem gerçekten değerbilir, hem de özverili insanlar oldukların bana, birbirlerine ve topluma gösterecekler. s. 100

\section{buluşum (randevu)}

Yanında bizim bilader dikiliyor. Yüksek Uzmanlık Hastanesinin beyin uzmanından buluşum almışlar. s. 109

Belediye Başkanı Kürşat Numanoğlu’ndan buluşum alpp yartm saat kadar konuştu. s. 120

\section{pastaevi (pastane)}

Kürşat Bey, karşıtlarına şehrin ortasında yeni açllan Nilsu Pastaevi’nde dondurma ısmarladı. s. 133

\section{armağan (hediye)}

Delikanlılar boyunlarma birer kuzu vursun; kadınlarımız armağan bohçaları alsın; gençlerimizin düğünlerine gelip gidelim. s. 136

\section{konuk (misafir) ${ }^{3}$}

3 "konuk" kelimesi kitapta sıklıkla geçtiği için bu örneklerin alınmasında sınırlamaya gidilmiştir. 
Daha Mustafa Bey İngilizce konuşmaya başlar başlamaz bir alkış koptu. Bu alkışı Amerikalı konuklar başlattı. s. 85 .

Öğleye doğru, beklenen konuklar gelmeye başladı. s. 101

Gidiyorum; çünkü sizin işiniz çoktur. Biz konuk için ufak tefek yolluklar, anmalıklar hazırlayacağız. s. 121

Birlikte buyurup gelin. Her zaman gelin, konuğumuz olun. s. 123.

\section{Sonuç ve öneriler}

Bu araştırmada, Fakir Baykurt'un Eşekli Kütüphaneci adlı romanı eş anlamlı kelimelerin öğretimi açısından değerlendirilmiştir. Eserde Standart Türkiye Türkçesinde geçiş sıklıkları yüksek olan bazı ödünç kelimelerin yerine Türkçe kökenli kelimeler kullanımı tercih edilmiştir.

Fakir Baykurt, romanında resepsiyon yerine yazıcl; mezar yerine gömüt, lokanta yerine doyumevi, sermaye yerine anapara, bina yerine yapı / yapt, servet yerine mall, sevda yerine sevi, hayat yerine yaşam, cevap yerine yant, futbol yerine ayaktopu, zengin yerine varsıl, fark yerine ayırt, faydalı yerine yarayışh, şöhret / nam yerine ün, vasıta yerine taşıt, hizmetli / müstahdem yerine işgören, cihaz yerine aygıt, hoparlör yerine sesbüyüten / sesdağıtan, emir yerine buyruk, misafirperver yerine konuksever, memnuniyet yerine hoşnutluk, sadelik yerine yalınlık, lider yerine önder, acele yerine ivedi, kadirşinas yerine değerbilir, randevu yerine buluşum, pastane yerine pastaevi, hediye yerine armağan ve misafir yerine konuk kelimelerini kullanmıştır.

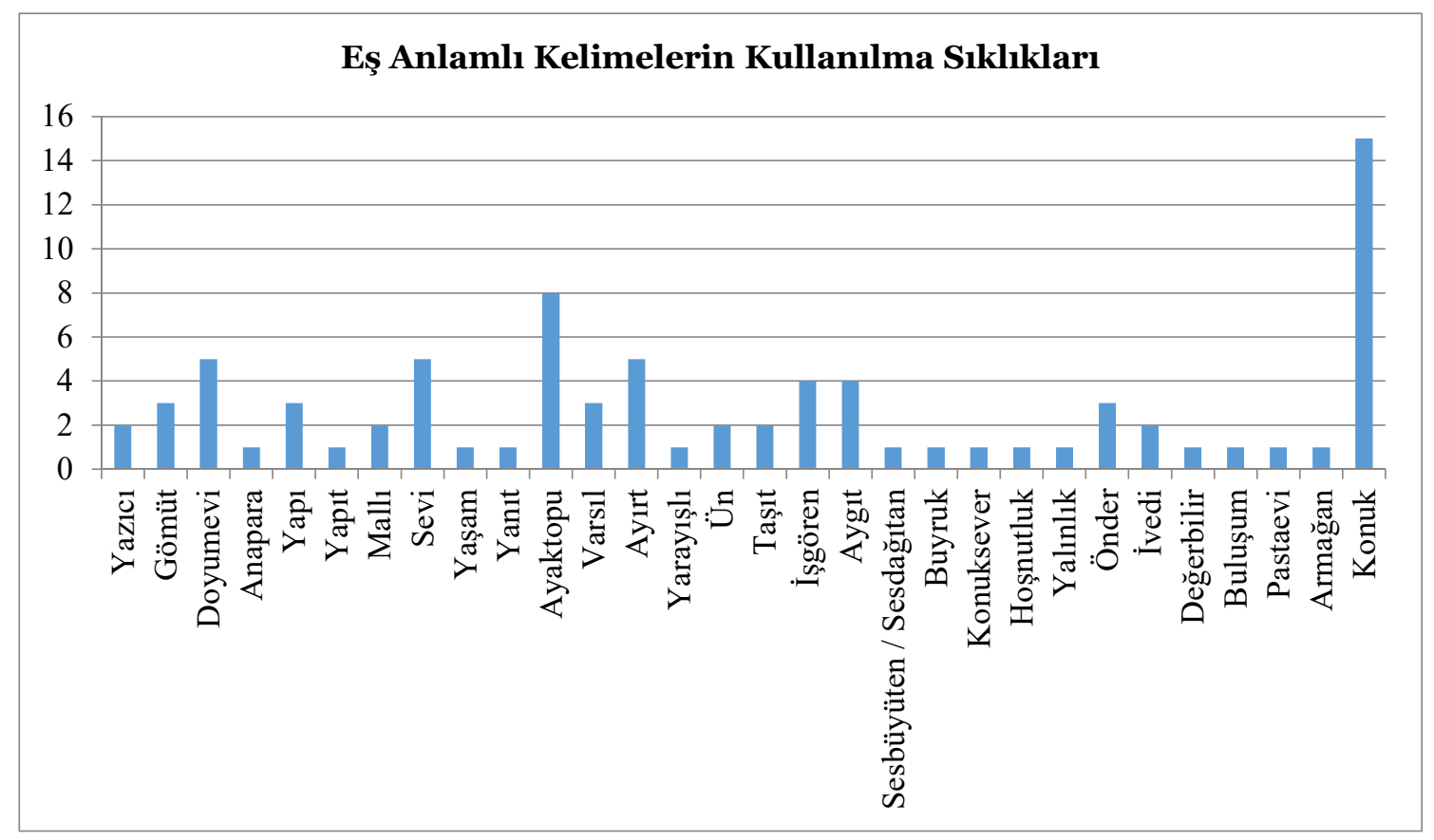

Şekil 1. Eşekli Kütüphaneci’de kullanılan eşanlamlı kelimelerin geçiş sıklıkları

Şekil 1'de Eşekli Kütüphaneci'de kullanılan eş anlamlı kelimelerden konuk, aygıt, işgören, ayırt, ayaktopu, sevi ve doyumevinin geçiş sıklıklarının 4 ve daha fazla kez olduğu tespit edilmiştir. Diğer kelimelerin geçiş sıklıklarının ise 1 ila $3 \mathrm{kez}$ arasında olduğu görülmektedir. 30 farklı kelimenin yerine toplam 80 kez eş anlamlıları kullanılmıştır. 
A review of the novel Eşekli Kütüphaneci by Fakir Baykurt with respect to the teaching of synonymous words / İ. Çoban; F. Polatcan (pp. 224-236)

İnsanları toplum içinde ön plana çıkaran özelliklerden biri kendini güçlü bir şekilde ifade edebilmektir. Bunun için de dil kuralları iyi bilinmeli ve sözcük dağarcığının olabildiğince zengin olması sağlanmalıdır. Sözcük dağarcığı, o dile ait edebî açıdan zengin kitapların okunmasıyla geliştirilebilir.

Türkçe derslerinde öğretimi yapılan eş anlamlı kelimelerin öğrencilerin zihninde kahıcılı̆̆ının sağlanması öğrencilerin bunları edebî ürünlerde görmesiyle daha kolay hâle gelecektir. Eserde ayrıca Türkçecilik bilincinin de hâkim olduğu görülmektedir. Eserin taşıdı̆̆ı bu özellikler sayesinde öğretmenler tarafından öğrencilere okuma tavsiyesi olarak verilmesi önünde bir engel bulunmamaktadır. Eserde ayrıca okuma eğitiminin nasıl gerçekleştirilmesi ile ilgili de ipuçlarına rastlanmıştır. Eserin okuma eğitimi açısından incelenmesi de ilgililerine olumlu katkılar sağlayacaktır. 


\section{Kaynaklar}

Aksan, D. (2006). Anlambilim anlambilim konuları ve Türkçenin anlambilimi. Ankara: Engin.

Akyalçın, N. ve Gürcü, H. (2017). Orhan Pamuk ve Fakir Baykurt'un iki romanında deyim, atasözü ve ikilemeler bakımından söz varlığı. Journal of Awareness, 2(3S), 55-67.

Altınörs, A. (2000). Dil felsefesi sözlüğü. İstanbul: Paradigma.

Alyılmaz, C. (2004). Eski Türkçenin söz varlı̆̆ıın düz ve ters dizimi. Ankara: Kurmay.

Başar, M., Batur, Z. ve Karasu, M. (2014). Kukset tekniğinin öğrencilerin zit ve eş anlamlı sözcükleri anlamalarına etkisi. Kastamonu Ĕ̆itim Dergisi, 22(3), 909-922.

Baykurt, F. (2019). Eşekli kütüphaneci. İstanbul: Literatür.

Bayraktar, İ. (2018). Ortaokul 5. sınıf Türkçe ders kitaplarında bulunan sözcük öğretimi etkinliklerinin incelenmesi. Journal of Language Research (JLR), 2(1), 1-7.

Büker, M. ve Zeytinkaya, D. (2013). Eş anlamlı ve zıt anlamlı kelime öğretiminin dil edinimindeki yeri ve önemi. Turkish Studies, 8(10), 185-191.

Büyüköztürk, Ş., Kılıç Çakmak, E., Akgün, Ö. E., Karadeniz, Ş. ve Demirel, F. (2016). Bilimsel araştırma yöntemleri. (20. Baskı). Ankara: Pegem Akademi.

Çeçen, M. A. (2007). Kelime hazinesinin geliştirilmesinde dikkat edilmesi gereken hususlar. Journal of Turkish Linguistics, 1(1), 116-137.

Demirezen, M. (1991). Türkçe'ye İngilizce'den geçen sözcükler ve eşanlamlılık. Dilbilim Araştırmaları 1991, 133-136.

Dilidüzgün, Ş. (2014). Türkçe öğretiminde sözcük öğretme yöntemlerinin yeterliliği. Adryaman Üniversitesi Sosyal Bilimler Enstitüsü Dergisi, 7(17), 233-258.

Dinç, E. (2013). Nitel araştırmalarda geçerlik, güvenirlik ve etik. (3. Baskı). Nitel araştırma desen ve uygulama için bir rehber içinde (s. 199-228). Ankara: Nobel Yayıncılık.

Doğan, N. (2011). Türkiye Türkçesi fiillerinde eş anlamlılık. Uluslararası Sosyal Araştırmalar Dergisi, 4(19), s. 78-88.

Efe, M. ve Asutay, H. (2018). Fakir Baykurt'un göçmen edebiyatındaki yeri. Balkan ve Yakın Doğu Sosyal Bilimler Dergisi, 4(2), 1-8.

Gündoğdu, A. E. (2012). İlköğretim altıncı sınıf Türkçe dersi sözcük öğretimi etkinliklerinin çeşitli değişkenler açısından incelenmesi. Uluslararası Türkçe Edebiyat Kültür Eğitim Dergisi, 1(1), 201-217.

Hızlan, D. (2001). Eşekli kütüphaneci'ye devlet ilgisi. Hürriyet gazetesi, 30.01.2001.

İmer, K., Kocaman, A. ve Özsoy, A. S. (2011). Dilbilim sözlüğü. İstanbul: Boğaziçi Üniversitesi Yayınevi.

Karadağ, Ö. (2013). Kelime öğretimi. İstanbul: Kriter.

Karatay, H. (2007). Kelime öğretimi. Gazi Eğitim Fakültesi Dergisi, 27(1), 141-153.

Korkmaz, Z. (2017). Dil bilgisi terimleri sözlüğ̈̈̈. Ankara: TDK Yayınları.

MEB (2019). Türkçe dersi öğretim programı (ilkokul ve ortaokul 1, 2, 3, 4, 5, 6, 7 ve 8. sinıflar). Ankara.

Öksüzoğlu, A. F. (2016). Ankara'da gezici kütüphane hizmetini başlatan belge. Türk Kütüphaneciliği, $30(2), 263-265$.

Özbay, M. ve Melanlığlu, D. (2008). Türkçe eğitiminde kelime hazinesinin önemi. Yüzüncü Yıl Üniversitesi Eğitim Fakültesi Dergisi, 5(1), 30-45.

Özden, H. İ. (2014). Türkiye Türkçesinde eş anlamlılık ve örtmece (tabu) kelimelerin eş anlamlılık içindeki yeri. KMÜ Sosyal ve Ekonomik Araştırmalar Dergisi, 16 (Özel Sayı I), 160-165. 
A review of the novel Eşekli Kütüphaneci by Fakir Baykurt with respect to the teaching of synonymous words / İ. Çoban; F. Polatcan (pp. 224-236)

Pilten, Ş. (2008). Türkçede eş anlamlılık. Yayımlanmamış Doktora Tezi. Ankara: Ankara Üniversitesi Sosyal Bilimler Enstitüsü.

Sarı, M. (2011). Türkiye Türkçesinde eş anlamlılık ile ilgili bazı sorunlar. Turkish Studies, 6(1), 533538.

Sert, G. (2019). Anlam alanı ve anlam ezgisi açısından eş anlamlı durum sıfatları: "muhtemel” ve “olası” örneği. Uluslararası Türkçe Edebiyat Kültür Eğitim Dergisi, 8(1), 93-121.

Suvağci, İ. (2019). Fakir Baykurt'un Almanya'yı anlatan hikâyelerinde eğitim sorunu. Van Yüzüncü Yıl Üniversitesi Sosyal Bilimler Enstitüsü Dergisi, 43, 105-122.

Ulutaş. B. (2015). Doküman analizi. (ed. Fatma Nevra Seggie ve Yasemin Bayyurt). Nitel araştırma yöntem, teknik analiz ve yaklaşımları içinde (s. 279-297). Ankara: Anı.

Vardar, B. (2002). Açılamah dilbilim terimleri sözlüğü. İstanbul: Multilingual.

Yanardağ, M. F. (2005). Fakir Baykurt'un hikâye ve romanlarını tema ve yapısı üzerine bir inceleme. Yayımlanmamış Doktora Tezi. Malatya: İnönü Üniversitesi Sosyal Bilimler Enstitüsü.

Yanardă̆, M. F. (2007). Fakir Baykurt'un hikâyelerinde tema. Beykent Üniversitesi Sosyal Bilimler Dergisi, 1(1), 227-263.

Yazıcı Okuyan, H. (2007). Fakir Baykurt romanlarına yansıyan Burdur'un söz varlı̆̆ı. I. Burdur Sempozyuтu: Bildiriler, 245-252.

Yıldırım, A. ve Şimşek, H. (2013). Sosyal bilimlerde nitel araştırma yöntemleri. (9. Baskı). Ankara: Seçkin. 